\title{
An Ever-Shadowed Past? Citizens' Attitudes towards the Dictatorship in Twenty-First Century Portugal
}

\author{
José Santana-Pereira, Filipa Raimundo \& António Costa Pinto
}

To cite this article: José Santana-Pereira, Filipa Raimundo \& António Costa Pinto (2016): An Ever-Shadowed Past? Citizens' Attitudes towards the Dictatorship in Twenty-First Century Portugal, South European Society and Politics, DOI: 10.1080/13608746.2015.1128667

To link to this article: http://dx.doi.org/10.1080/13608746.2015.1128667

曲 Published online: 22 Feb 2016.

Submit your article to this journal $₫$

Џll Article views: 75

View related articles

View Crossmark data $\asymp$ 


\title{
An Ever-Shadowed Past? Citizens' Attitudes towards the Dictatorship in Twenty-First Century Portugal
}

\author{
José Santana-Pereira, Filipa Raimundo and António Costa Pinto
}

\begin{abstract}
Several years after the transition to democracy, positive attitudes towards the authoritarian past are still observable in Portugal: the belief that the previous regime had more good things than bad things is expressed by about one-fifth of the Portuguese. What explains this nostalgic sentiment? Are factors such as socialisation under the regime, party identification or religiosity more important than satisfaction with democracy and the state of the economy? The empirical analysis suggests that the relevance of these factors varies considerably, but socialisation phases lead to different stances on the past both in routine times and in times of economic crisis.
\end{abstract}

\section{KEYWORDS}

Portugal; attitudes towards the past; dictatorship;

socialisation; nostalgia

There is a growing stream of literature investigating the persistence of authoritarian values in democratic and quasi-democratic countries, among both citizens and elites (Stevens, Bishin \& Barr 2006; Pietsch, Miller \& Karp 2015). Yet little attention has been paid to the issue of how citizens and elites in democratic countries evaluate the authoritarian past in which part of the population has been socialised. We argue that understanding how citizens feel about the political regime that preceded their democracy may contribute to a better understanding of voters' preferences and voting behaviour. It may also bring into evidence the existence of dormant issues, i.e., issues that may not appear to be salient but which may resurge at any point. In addition, it may allow us to extract some conclusions about the authoritarian regime itself, particularly its socialisation and indoctrination capacity.

This article explores citizens' attitudes towards the authoritarian past in a country that was ruled by a right-wing fascist-type dictatorship for almost fifty years: Portugal. We take advantage of the fact that, forty years after the breakdown of the dictatorship, there is still a sizable cohort of individuals who were at least 21 years old in 1974 and who lived and were socialised under the previous regime.

Portugal was the first country of the third wave of democratisation to initiate its transition to democracy, but its authoritarian regime was one of the longest in twentieth-century Europe, lasting from 1926 to 1974. Salazar's regime outlived all other inter-war dictatorships (with the exception of Francoism), surviving well beyond the post-war period. After 1945, the regime forcefully held on to its African territories while facing increasingly strong international pressures to decolonise. Between 1961 and 1974, a large segment of the population was affected by a three-stage colonial war in Angola, Guinea-Bissau and Mozambique. ${ }^{1}$ And 
on 25 April 1974, partly in reaction to the never-ending wars against the independent movements in those countries, a group of middle-rank military staged a coup that brought down the authoritarian regime in an abrupt yet non-violent manner - the so-called 'Carnation Revolution' - followed by a comprehensive transitional justice process (Pinto and Raimundo 2014). In six years, Portuguese democracy was fully consolidated and in 1986 the country became a full European Economic Community member-state.

Today, forty years after the beginning of the transition to democracy, some positive attitudes towards the authoritarian past still persist. In the past 15 years, both the Research Centre of Public Opinion at the Portuguese Catholic University (CESOP/UCP) and the Quality of Democracy Barometer of the Institute of Social Sciences, University of Lisbon (BQD/ICS) have carried out surveys on the occasion of the 30th and 40th anniversaries of the Carnation Revolution.

According to the data produced by these surveys, there is still a surprising number of Portuguese citizens who believe the authoritarian regime had more positive than negative aspects: 19 per cent in 2004 and 21 per cent in 2014. If we add to these figures the individuals who evaluate the previous regime as having had as many good things as bad things, the percentages increase to 47 and 53 per cent in 2004 and 2014, respectively (Figure 1). This means not only that one in every five citizens believes that the Estado Novo (New State, the Portuguese authoritarian regime) had more positive than negative features, but also that there is a cleavage between those who consider the regime to have been relatively negative and those who see it as a neutral or relatively positive experience. Also, it seems that neutral and positive assessments of the political past increased slightly between 2004 and 2014. Thirty and forty years after the revolution, and in the context of an absence of political discourse about the past (Raimundo 2012), these findings are striking.

The goal of this article is to identify the factors underlying the assessment of Salazar and Caetano's dictatorship, decades after the democratic consolidation in Portugal, in light of the existing literature. We examine those societal attitudes by focusing particularly on the positive attitudes expressed by a minor but sizable share of the population, distinguishing between two socialisation phases of different length under the authoritarian regime: first, the years from institutionalisation to the beginning of the colonial wars, and second, from the beginning of the colonial wars until the military coup of 1974.

The first phase of the Portuguese regime (1932-60) can in fact be divided in two. From 1932 to 1944 , the Portuguese dictatorship was strongly associated with European fascism. In its early years, the regime openly expressed its authoritarian values, backed by a propaganda apparatus, youth paramilitary organisations, militias and strong political repression. In addition, the regime implemented a policy of 'Christianising' institutions and the school system in close association with the Catholic Church, through a common corporatist, anti-liberal and anti-communist ideological and political nucleus. After 1945, with the end of the Second World War, a new period began in which the dictatorship had difficulties in adapting to the new international scene. This led to changes that increased the regime's limited pluralism. In this period, the Church gradually became an ideological haven, and the vitality of the Catholic organisations increased. Traditional Catholicism and the Church were, on the one hand, the dictatorship's most powerful weapons; on the other hand, they limited 'fascistisation', becoming the driving force of the New State's limited pluralism (Pinto 2011). Since we do not expect these two phases to have considerably different outcomes in terms of socialisation, we do not separate the two periods in the empirical analysis carried out in this article. 


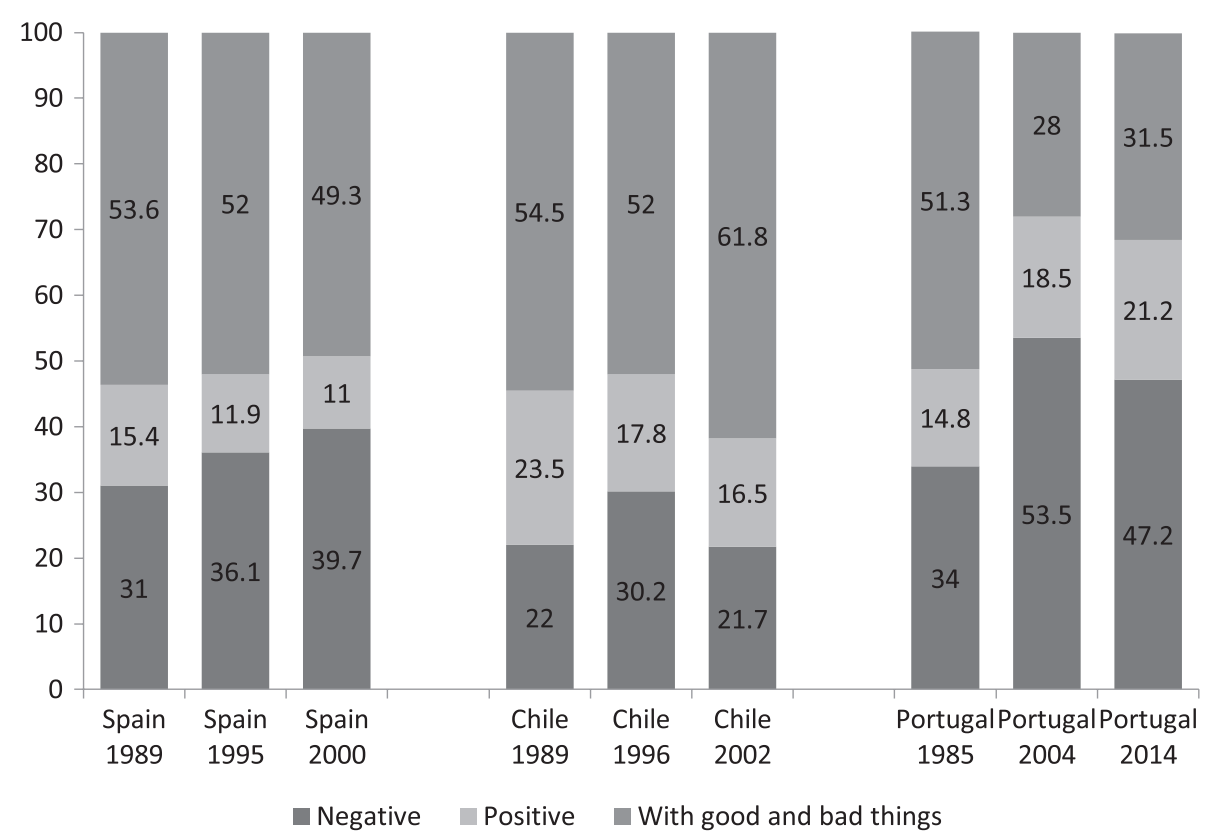

Figure 1. Attitudes towards the authoritarian past in Spain, Chile and Portugal (per cent of respondents in each category; valid percentages).

Notes: In Portugal 2004 and 2014, the first and the second possible answers were slightly different from those included in the Spanish and the Chilean questionnaires: instead of 'negative', 'more bad things than good things'; and instead of 'positive';'more good things than bad things'. These were, respectively, the most negative and the most positive categories in the scale used by the Portuguese surveys, which makes its comparison with the'negative' and 'positive' categories in the Spanish and Chilean surveys possible. The data for 1985 was retrieved from Sani et al. (1985, available in Freire et al., 2005).

The second phase (1961-74) was characterised by modernisation, political turmoil, the impact of the colonial wars in Africa, a certain degree of international criticism of the regime, and the replacement of Salazar by Caetano (in 1968). This phase may have had a greater impact in people's lives than the previous one, given the war effort. In fact, the proportion of the Portuguese population under arms in Africa (140,000 men) was only exceeded by Israel and North and South Vietnam.

The article is organised as follows. The next section explores the existing studies on attitudes towards authoritarianism and authoritarian pasts and examines the results of previous studies on Portuguese attitudes towards the New State. The following section presents the data, the hypotheses and the statistical results, showing that, contrary to what we might expect, the factors that explain the attitudes towards the past in 2004 fail to do so in 2014. The article ends with some tentative conclusions regarding the attitudes towards the past in Portugal and suggests avenues for future research.

\section{Attitudes towards the past in post-communist and post-authoritarian democracies}

Public opinion studies conducted in post-authoritarian democracies usually focus on democratic attitudes and authoritarian values and only occasionally on attitudes towards the authoritarian past itself (Stevens, Bishin \& Barr 2006; Chu et al. 2008; Mattes 2012; 
Pietsch, Miller \& Karp 2015). This is probably a consequence of the reduced number of survey questions measuring citizens' feelings about the regime they or their relatives have been socialised in. To our knowledge, there is but a handful of countries where data on societal attitudes towards the authoritarian past have been collected on a regular basis, hence there are few individual, let alone comparative, studies on attitudes towards the past.

In 1972, Samuel Barnes wrote a pioneer study on political attitudes in post-fascist Italy. Using data extracted from a 1968 public opinion study, the author evaluated the extent to which Italian fascism had been able to indoctrinate its citizens and the impact of socialisation under fascist institutions. Barnes assumed that 'if the age cohorts that reached maturity during the fascist era were indeed effectively socialised by the regime, some residues should remain in their political attitudes and behaviour that set them apart from those socialised before and after' (Barnes 1972, p. 46). He concluded that there were very few traces of fascist ideology in the cohorts that had been socialised under Mussolini's regime, which did not come as a surprise, given the medium level of institutionalisation of the fascist regime and its inability to overcome powerful traditional institutions such as the Catholic Church.

The Four Nation Survey, implemented almost twenty years later in Portugal, Spain, Italy and Greece, showed that 15 per cent of Portuguese respondents considered that, overall, Salazar's regime was good for the country (against 19 per cent of Spaniards assessing Franco's regime in the same way). Interestingly enough, in the four countries, around 50 per cent of citizens assessed the regimes of Salazar, Franco, Mussolini and the Colonels as having been partially good and partially bad for their respective countries (Sani et al. 1985). Positive attitudes towards the previous regime were at the time higher in Portugal and Spain than in Italy and Greece. Although the authors suggest that this may be linked to the duration of the Iberian dictatorships and therefore be expressed by the older generations, no statistical analysis has been provided to support this claim.

In 1998, Morlino and Mattei interpreted the share of positive attitudes towards the previous regime as a sign of potential support for authoritarianism. When they looked at the 1985 data their conclusion was that 'room exists for a new authoritarianism at least in Italy and Portugal' (Morlino \& Mattei 1998, p. 1,756). Today we know that there is not necessarily a link between authoritarian values and support for democracy, something that was acknowledged by Morlino and Montero in 1995.

We argue that exploring the determinants of attitudes towards the past, and particularly nostalgia - broadly understood as the persistence of positive attitudes towards the past - is both relevant and necessary, in the context of both transitional societies and fully consolidated democracies, as it can shed light on the elite's or citizens' political preferences and patterns of socialisation.

The region where the legacies of the past have been more thoroughly analysed is post-communist Europe. Studies focusing on post-communist countries are probably the richest where respondents have been asked to make a retrospective evaluation of the old regime. These studies have essentially made use of the New Europe Barometer data, which includes three relevant questions: 'Where on this scale would you put the former Communist regime?', 'With which of the following do you most closely identify with?' and 'Should we return to Communist rule?' Some of these questions are used precisely to measure the percentage of citizens who are nostalgic for the old regime, but the conclusions are contradictory. ${ }^{2}$ 
First, Ekman and Linde (2005, p. 26) argue that nostalgia is related to age: 'the older the respondents, the more likely they are to express feelings of nostalgia'. More recently, PopEleches and Tucker (2014) have taken a different approach to age, looking predominantly at the effects of exposure to different types of communism. Their conclusion is that the longer the period of exposure to communism, the higher the levels of opposition to democracy. Second, Ekman and Linde (2005) argue that nostalgia is not so much the expression of nondemocratic values as a negative evaluation of the present situation. Looking at the same cases, Gherghina and Klymenko (2012) reach a different conclusion. They argue that nostalgia is driven not so much by an evaluation of present and recent experiences and rather by retrospective evaluations and memories of the past, where socialisation appears to play a crucial role. Lastly, studies on post-communist nostalgia have predominantly explored the relationship between nostalgia among the (economic) winners and losers of the transition. These studies have found that nostalgia is most prevalent among coal miners and private farmers and less so among office employees and skilled workers (Kurczewski 1994).

Among (right-wing) post-authoritarian countries where data on attitudes towards the past has been collected on more than one occasion, the case of Spain is particularly interesting for our study. After Portugal, Spain had the second-longest dictatorship in Europe. Yet differently from what happened in Portugal, the Francoist regime emerged out of a brutal civil war and came to an end through a process of ruptura pactada initiated with Franco's death in 1975. A survey conducted in 1978 by the FOESSA (Fomento de Estudios Sociales y de Sociologia Aplicada - Promotion of Social Studies and Applied Sociology) Foundation has shown that - following a period of uncertainty regarding the transition and the ability of the new democratic elite to maintain peace in the country - more than 75 per cent of respondents agreed that the Francoist regime was characterised by social inequality, repression and lack of freedom, but an equally high 68 per cent believed that under Franco Spain had developed economically and that 'nearly all Spaniards lived better although some benefited more than others' (Aguilar Fernández 2009, p. 461). According to Aguilar Fernández, 'there was still significant backing for a benevolent assessment of the dictatorship, based mainly on what has since been called "performance-based legitimacy"' (Aguilar Fernández 2009, p. 461). The Centro de Investigaciones Sociológicas (CIS - Centre for Sociological Research) also collected data on attitudes towards the Francoist regime on more than one occasion. ${ }^{3}$ Their data seem to confirm the interpretation by Montero and Torcal according to which after the 1980s the historical evaluation of the Francoist period became less straightforward. In other words, even though the percentage of negative evaluations tends to increase, a majority of the respondents seems to have opted for an ambivalent position (Montero \& Torcal 1990, p. 55; see also Gunther, Montero \& Botella 2004).

In Chile, where there was also a negotiated transition to democracy, similar questions have been posed on a number of occasions. Yet, unlike in Spain, the Chilean dictator, Pinochet, was not only alive but also strongly present in the country after the transition to democracy, first as commander-in-chief of the Chilean Army and later as senator for life. ${ }^{4}$ Huneeus (2003) shows that individuals who place themselves on the right tend to say that the Pinochet years were positive and those who place themselves on the left evaluate the regime negatively. There is also a strong relationship between voting for a particular party and the evaluation of the regime. Interestingly, the author identifies a group of nostalgic individuals whom he describes as those who'admit the existence of democracy, without fighting against it, but who make no efforts to contribute to its success' (Huneeus 2003). 
In Portugal, a study carried out in 1978 by Bacalhau and Bruneau showed that about 35 per cent of the interviewees depicted Caetano's and Salazar's rule as better than the governments formed after April 1974, while more than 40 per cent did not know or refused to reply. ${ }^{5}$ This means that in 1978 the authoritarian rulers were relatively more popular than the prime ministers in the first years of the transition (Bacalhau \& Bruneau 1978; see Freire et al. 2005). In addition, Caetano - Salazar's replacement after the dictator became severely ill in 1968 - tends to perform better than Salazar in terms of government assessment. In 1984, the situation is similar: despite the fact that now only about 21 per cent of the interviewees say they don't know or refuse to answer, those who preferred the government of Salazar and Caetano still outnumber those who believe that the best government was one of the cabinets formed after 1974; again, amongst the dictators, Caetano is preferred to Salazar (Bruneau \& Bacalhau 1984; see Freire et al. 2005).

The studies carried out in Spain and Chile allow us to compare Portugal with fairly similar situations. Figure 1 compares data for the three countries in three different years, and allows us to identify different patterns: Spain, where the levels of public debate about the past are relatively high (Aguilar Fernández 2008) and most people tend to look at Franco's regime as not particularly good or bad; Chile, where the politicisation of the past is very strong, the majority of the population has neutral attitudes towards the authoritarian regime, but the proportion of people who assess positively the authoritarian rule is higher than in Spain (though declining); and lastly, Portugal, a country in which the past is hardly an issue in the political sphere (Raimundo 2012), whose general panorama in 1985 was similar to that of Spain and is nowadays characterised by higher proportions of citizens evaluating Salazar's regime as mainly negative or mainly positive.

Despite the scarcity of theory on the correlates of attitudes towards the past, the present article explores some of the existing studies, building on their main conclusions. The studies focusing on the factors underlying the attitudes towards the past have identified the role played by dimensions such as party identification (in Chile, where the issue is politically relevant; Huneeus 2003), assessments of the current situation (Ekman \& Linde 2005) and socialisation (Gherghina \& Klymenko 2012). These explanatory factors are tested in the following section, in which a model of attitudes towards the authoritarian regime in Portugal will be empirically tested.

\section{Attitudes towards the past in Portugal, 2004 and 2014}

\section{Goals, hypotheses, data}

The goal of the present article is to identify the factors underlying the assessment of the Salazar and Caetano's dictatorship, several decades after the transition to democracy. In a context where democracy has been the only game in town for a long time, there is a surprisingly large number of citizens who believe that the authoritarian regime had more positive than negative aspects: 19 per cent in 2004 and 21 per cent in 2014.

Based on the literature on nostalgia towards the non-democratic past focused on other countries, we derived several hypotheses about the factors that may impact on attitudes towards the authoritarian regime in Portugal. We organise our hypotheses in three groups: socialisation or personal experience, party identification, and assessments of the current status quo. 
The first two hypotheses concern socialisation, one of the main bases for attitudes towards the past in post-communist countries (Gherghina \& Klymenko 2012). Following Pop-Eleches and Tucker (2014), we are interested in analysing the differential impact of exposure to different phases of the authoritarian regime in Portugal. First, we expect people who were fully socialised in the first period of the authoritarian regime (i.e. before the start of the Portuguese colonial wars in Africa) to be more positive towards the regime, due to the strong indoctrination effect of schooling and other socialisation agents in that era. In other words, we expect these attitudes to be more positive for those who were born between 1927 and 1940, and therefore lived their impressionable years (Krosnick \& Alwin 1989) entirely in this context. Second, we expect the respondents who were fully socialised after the Carnation Revolution, i.e., those who were born in or after 1968, to be more negative in their evaluations of the previous regime than the others, since the general environment in which their socialisation took place should have led to the adoption of values that are not congruent with a positive assessment of a dictatorial regime. In methodological terms, the creation of two dummy variables (one distinguishing the first group, composed of the older respondents, and the second distinguishing the younger cohorts) causes the middle-age cohorts (those born between 1941 and 1967, who were either socialised in different contexts or fully socialised in the last, less stable, phase of the New State), who are expected to hold milder attitudes vis-à-vis the former groups, to function as a reference category.

H1: Citizens who were socialised during the first period of the authoritarian regime (1932-61) will display more positive attitudes towards this regime.

H2: Citizens who were socialised during democracy will present more negative attitudes towards the authoritarian regime.

The following two hypotheses deal with the impact of party attachments on attitudes towards the political past. These hypotheses are partly drawn from the results of research on Chile (Huneeus 2003), but also from previous research on elite attitudes towards the past in Portugal (e.g. Raimundo 2012). The Portuguese left is characterised by parties associated with the antifascist struggle and the opposition to the previous regime: the centre-left Partido Socialista (PS - Socialist Party), the communist/green stable coalition Coligação Democrática Unitária (CDU - Unitary Democratic Coalition) and the Bloco de Esquerda (BE - Left Bloc). Therefore we can expect citizens who feel close to those parties to express more negative attitudes towards the past. On the centre-right, existing research shows that the main party, Partido Social Democrata (PSD - Social Democratic Party), has an ambivalent position, and its preferred option has been to remain silent and express neutral views of the past (Raimundo 2015). On the right, the CDS-PP (Partido Popular - Popular Party) has been the most active in bringing issues that relate to the past on to the agenda. In particular, during recent years, the CDS-PP has made the issues of decolonisation and the acknowledgement and compensation of the combatants one of its flags. For that reason, we should expect citizens who identify themselves with CDS-PP to express less negative views of the past. While we know that the patterns of party polarisation around this issue are much lower than in Chile, we expect that party identification will nevertheless play a role.

H3: Citizens who feel close to right-wing parties (namely CDS-PP) are more likely to display positive assessments of the authoritarian regime.

H4: Citizens who are close to left-wing parties such as PS, BE or CDU will have more negative attitudes towards the authoritarian regime. 
The last set of hypotheses deal with assessments of the status quo in the country, which have been identified as factors in attitudes towards the non-democratic past by previous research (Ekman \& Linde 2005). In this study, we are interested in the impact of satisfaction with the way democracy functions, and the personal financial situation of the respondents. Due to lack of data on economic conditions and perceptions of the interviewees, the latter is operationalised through data on work situation, namely by means of a dummy variable distinguishing the unemployed from the other respondents.

H5: Low levels of satisfaction with the way democracy works are associated with positive assessments of Salazar's regime.

H6: Unemployed citizens will be more likely to assess the authoritarian regime positively than others.

This article rests on survey data collected in 2004 by the Public Opinion Study Centre of the Portuguese Catholic University and in 2014 by the Quality of Democracy Barometer of the Institute of Social Sciences, University of Lisbon. These two years were not selected randomly: in fact, both surveys were carried out right before the celebration of the 30th and the 40th anniversaries of the Carnation Revolution that paved the way for the establishment of a democratic regime in Portugal. In 2004, 1,216 citizens were interviewed, while in 2014 the sample was composed of 1,256 respondents. The independent (socialisation phases, party identification, assessment of the status quo), dependent (attitudes towards the New State) and control variables (gender, education and religiosity) tested in the next subsection are described in Table 1.

Table 1. Variables used in the regression models.

\begin{tabular}{|c|c|c|}
\hline Variable & Question used (our translation) & Final scale \\
\hline \multicolumn{3}{|l|}{ Dependent } \\
\hline $\begin{array}{l}\text { Assessment of the authoritarian } \\
\text { regime }\end{array}$ & $\begin{array}{l}\text { According to your experience or } \\
\text { what you heard, how do you think } \\
\text { that the political regime that existed } \\
\text { before } 25 \text { April } 1974 \text { should be } \\
\text { portrayed? }\end{array}$ & $\begin{array}{l}\text { Three-point scale: } 1=\text { as a period } \\
\text { with more bad things than good } \\
\text { things, } 2=\text { as a period with as many } \\
\text { good things as bad things, } 3=\text { as a } \\
\text { period with more good things than } \\
\text { bad things }\end{array}$ \\
\hline \multicolumn{3}{|l|}{ Independent } \\
\hline $\begin{array}{l}\text { Socialisation in the first period of the } \\
\text { New State }\end{array}$ & How old are you? & $\begin{array}{l}1=\text { citizens born in or after } 1927 \\
\text { who completed } 21 \text { years of age in or } \\
\text { before } 1961\end{array}$ \\
\hline Socialisation in democracy & How old are you? & $1=$ citizens born in or after 1968 \\
\hline Party identification & $\begin{array}{l}\text { Do you feel close to any political } \\
\text { party? If yes, which one? }\end{array}$ & $\begin{array}{l}\text { Several dummies: BE, CDU, CDP-PP, } \\
\text { PS, PSD }\end{array}$ \\
\hline Satisfaction with democracy & $\begin{array}{l}\text { In general, are you very satisfied, } \\
\text { reasonably satisfied, not very } \\
\text { satisfied or not satisfied at all with } \\
\text { the way democracy works? }\end{array}$ & $\begin{array}{l}\text { Four-point scale: } 1 \text { (not satisfied at all) } \\
\text { to } 4 \text { (very satisfied) }\end{array}$ \\
\hline Work status & What is your current work situation? & $1=$ respondent is unemployed \\
\hline \multicolumn{3}{|l|}{ Control } \\
\hline Gender & Registered by interviewer & $1=$ female \\
\hline Religiosity & $\begin{array}{l}\text { Do you consider yourself to be } \\
\text { very, reasonably, somewhat or not } \\
\text { religious at all? }\end{array}$ & $\begin{array}{l}\text { Four-point scale: } 1 \text { (not religious at } \\
\text { all) to } 4 \text { (very religious) }\end{array}$ \\
\hline Education & $\begin{array}{l}\text { What was the highest educational } \\
\text { level that you completed? }\end{array}$ & $\begin{array}{l}6 \text { categories: } 1 \text { (less than elementary) } \\
\text { to } 6 \text { (university-level) }\end{array}$ \\
\hline
\end{tabular}




\section{Results}

In the next paragraphs, the results of two ordinal logistic regression models using the variables mentioned above as factors of the assessment of Salazar's regime ${ }^{6}$ in 2004 and 2014 are presented and discussed.

The first two columns in Table 2 display the results for 2004. We start by stressing that two out of the three control variables, namely education and religiosity, are relevant factors of attitudes towards the past. Indeed, the more educated the respondents are, the less likely they are to assess the New State in a positive fashion. The poorly educated have a 76 per cent probability of assessing the previous regime as negative and an 11 per cent probability of assessing it positively. On the contrary, people who attended university are only five per cent likely to express positive attitudes and 87 per cent likely to be negative towards the past. Also, the more religious the respondents report themselves to be, the less likely they are to display a negative appraisal of Salazar's regime. When the other factors are kept constant at their mean values, strongly religious respondents have a 78 per cent probability of displaying negative judgements and a ten per cent probability of expressing positive attitudes towards the past. In turn, those who are not religious are 85 per cent likely to be negative and only six per cent likely to be positive towards the New State.

Regarding the personal experience variables, socialisation under the first period of authoritarian rule (that is, before 1961) has a significant impact. This means that only Hypothesis 1 is empirically supported: when we keep the other factors constant at their

Table 2. Determinants of the assessment of the Estado Novo in 2004 and 2014: ordinal logistic regressions.

\begin{tabular}{|c|c|c|c|c|}
\hline & \multicolumn{2}{|c|}{2004} & \multicolumn{2}{|c|}{2014} \\
\hline & Coeff. & $\begin{array}{l}\text { Average } \\
\text { discrete } \\
\text { changes }\end{array}$ & Coeff. & $\begin{array}{c}\text { Average discrete } \\
\text { changes }\end{array}$ \\
\hline Threshold $=1$ & $-0.34(0.33)$ & & $0.22(0.31)$ & \\
\hline Threshold $=2$ & $1.08^{* *}(0.33)$ & & $1.67^{* * *}(0.31)$ & \\
\hline Gender (Female) & $-0.18(0.13)$ & 0.02 & $-0.04(0.12)$ & 0.01 \\
\hline Education & $-0.15^{* *}(0.05)$ & 0.07 & $0.04(0.05)$ & 0.01 \\
\hline Religiosity & $0.17^{*}(0.08)$ & 0.05 & $0.11(0.07)$ & 0.02 \\
\hline $\begin{array}{l}\text { Socialisation in first phase of } \\
\text { New State }\end{array}$ & $0.50 * *(0.18)$ & 0.06 & $-0.43(0.25)$ & 0.04 \\
\hline Socialisation in democracy & $-0.03(0.15)$ & 0.01 & $-0.27 *(0.13)$ & 0.06 \\
\hline CDU & $-0.80 *(0.34)$ & 0.07 & $-0.13(0.27)$ & 0.02 \\
\hline PS & $-0.57^{* *}(0.17)$ & 0.05 & $0.13(0.16)$ & 0.02 \\
\hline PSD & $0.13(0.17)$ & 0.01 & $0.28(0.19)$ & 0.04 \\
\hline CDS-PP & $0.48(0.43)$ & 0.03 & $0.28(0.59)$ & 0.04 \\
\hline $\mathrm{BE}$ & $-1.19 *(0.50)$ & 0.08 & $-0.19(0.37)$ & 0.03 \\
\hline Satisfaction with democracy & $-0.14(0.08)$ & 0.06 & $-0.01(0.08)$ & 0.01 \\
\hline Work status (unemployed) & $-0.07(0.24)$ & 0.01 & $0.32 *(0.16)$ & 0.05 \\
\hline$N$ & \multicolumn{2}{|c|}{1,006} & \multicolumn{2}{|c|}{1,098} \\
\hline Pseudo $R^{2}$ (Nagelkerke) & \multicolumn{2}{|c|}{$8.2 \%$} & \multicolumn{2}{|c|}{$1.9 \%$} \\
\hline Model fitting (chi-squared) & \multicolumn{2}{|c|}{$74.3^{* * *}$} & \multicolumn{2}{|c|}{$18.76^{*}$} \\
\hline
\end{tabular}

Source: CESOP Survey on the 30th Anniversary of the Carnation Revolution; Quality of Democracy Barometer Survey on the 40th Anniversary of the Carnation Revolution.

Notes: In the first column, values are unstandardized coefficients, with standard errors in parentheses. In the second column, values are the changes in the probability of holding different attitudes caused by shifting from the minimum to the maximum value of the independent variable, when all the other variables are held at their mean. Multicollinearity diagnostics give negative results: no variance inflation factors (VIFs) higher than $2 .{ }^{* *} p<0.001 ;{ }^{* *} p<0.010 ;{ }^{*} p<0.050$. 
means, the probability of assessing the New State positively is 12 per cent for those who were socialised in that period and only seven per cent for people born between 1941 and 1967 (the baseline category). The latter group - composed of those who were socialised during the second phase of the regime - have a 82 per cent probability of holding negative attitudes towards the authoritarian regime, while the older group is only 74 per cent likely to express such judgements. Unlike our expectations, the assessment of Salazar's regime made by those socialised under a democratic regime is not statistically different from the judgement expressed by the intermediate socialisation group. In short, socialisation seems to matter, but the cutting point is around 1961, the beginning of the New State's second, more turbulent, phase.

Party attachments are also relevant factors of attitudes towards the past. In fact, all but two of the party identification dummies are statistically significant. Identification with leftwing parties (CDU, BE, PS) raises the probability of assessing the New State negatively from around 79/80 per cent to around 87 (PS) or 93 per cent (BE). In the same vein, the likelihood of being positive towards the authoritarian regime is about eight per cent for those who do not feel close to these parties and considerably lower (between three and five per cent) for those who identify with them. Hypothesis 4 is therefore supported by this empirical evidence. Interestingly, identification with right-wing parties (PSD and CDS-PP) has no significant impact. While these results are generally in line with our expectations, the fact that identification with the most right-wing party with parliamentary representation in the Portuguese political system (CDS-PP) is not at all connected with attitudes towards the previous right-wing authoritarian regime is striking.

Also surprising is the fact that, in 2004, evaluations of the way democracy works do not have an impact in the assessment of the past regime, nor does the financial situation of the respondents (measured through a proxy, i.e. whether they are unemployed). Unlike what happens in other contexts (Ekman \& Linde 2005), it would seem that the Portuguese citizens did not express attitudes towards the past in a strategic way, as a means of criticising or supporting the current state of things in the country.

In sum, the specific time of socialisation and party attachments (especially identification with left-wing parties) are the most significant factors behind the attitudes towards the authoritarian regime in Portugal, 30 years after the Carnation Revolution. Interestingly enough, these attitudes are not linked to partisan attachment to the main centre-right party in Portugal (PSD) - which constitutes evidence of a poor politicisation of the past by this party vis-à-vis other parties in the Portuguese political spectrum (Raimundo 2015) - or to the right-wing party CDS-PP, which, however, has tried to put some issues relating to the past on the political agenda (Raimundo 2012). The average discrete changes ${ }^{7}$ show that there is a considerable degree of balance in the impact of these factors, even if identification with the new left BE or the communist/green coalition CDU seems to explain more variance in the attitudes held by the Portuguese than does socialisation or identification with the centre-left PS.

Let us now have a look at the data for 2014 (Table 2). There are considerable differences between the results discussed above and those estimated for this year. First, education and religiosity are no longer relevant. Second, socialisation is still relevant, but now the differences are between those who were socialised under the democratic regime and the others. The former have less positive attitudes towards the previous regime than the intermediate socialisation group, which is not significantly different from the older group. 
When the other variables are held constant, the likelihood of holding negative attitudes towards the previous regime is 69 per cent for those who were not socialised under the dictatorship and 63 per cent for the others. In the same vein, the probability of assessing the New State positively is 18 per cent for the older and 14 per cent for the younger group.

In 2004, it was not this dichotomy that made the difference in terms of attitudes towards the past, but the cleavage between those who were fully socialised before 1961 and those who were not. The differences vis-à-vis 2004 may be partly explained by the entry of a new generation in the younger group (those born between 1986 and 1999, who were not interviewed in 2004 and whose attitudes towards the past are fairly negative -1.7 on a threepoint scale) and the exit of a generation in the older group: those who were born before 1930 (6.5 per cent of the sample in 2004 but only one per cent of the sample in 2014), who were more positive about the New State (average assessment of 2 on a three-point scale). In 2014, these events stressed the cleavage between those who were fully socialised after 1974 and the intermediate socialisation group and nuanced the differences amongst those who were fully socialised before 1961 and that same reference group.

Unlike our expectations, the impact of relatively stable political attitudes such as party identification is not statistically significant (Table 2). Aside from socialisation under the democratic regime, the only relevant factor is work status, those who were not working at the time of the interview being more likely to assess the previous regime positively. The unemployed are 20 per cent likely to be positive towards the New State and 60 per cent likely to disapprove of it, while those whose job situation is different are only 15 per cent likely to favour the previous regime but 67 per cent likely to reprove it.

\section{Conclusions}

In this article we tested a model aimed at explaining the variance in the attitudes towards the past amongst Portuguese citizens at two different points in time: 2004 and 2014. The results allow us to conclude that the factors underlying these attitudes are unstable, having varied considerably in one decade. In terms of the socialisation factors, while in 2004 it seemed that what mattered was having been socialised before 1961, in 2014 the key factor was having been socialised after the Carnation Revolution (1974). Our expectations about the impact of partisan attachments are empirically supported in 2004, but not in 2014, which suggests that the authoritarian past as an issue was depoliticised between 2004 and 2014. Meanwhile, the impact of short-term variables such as being unemployed is observable only in 2014 .

Let us take a closer look at the patterns observed. In 2004, an array of variables of different nature (the specific period of socialisation, party attachments, but also religiosity and education) had an impact on the expression of positive or negative attitudes towards the New State. In short, socialisation before 1961 and religiosity foster positive assessments of the previous regime, while education and closeness to left-wing parties such as PS, CDU or BE lead to more negative assessments of Salazar's rule. As expected, attitudes towards the past are not linked to identification with the centre-right PSD, due to the low levels of politicisation of the past by this party in the years that followed the Carnation Revolution (Raimundo 2015). The same holds true for identification with the right-wing CDS-PP, which has, however, a different record in terms of its relationship with the authoritarian past. 
In 2014, the patterns observed ten years before are no longer present. Only socialisation under democratic rule and work status explain the variation in attitudes towards the past. Although modest, the impact of the variable'work status' on attitudes towards the past allows us to hypothesise that, in a situation of economic and financial crisis (with the related negative impact in terms of trust in political institutions) it is not stable political predispositions but short-term assessments of the current situation that influence people's evaluation of the dictatorship that was in place until 1974. In other words, displaying positive attitudes towards the previous regime may be a form of protest against the crisis, the government, the traditional political parties, the austerity measures and the national and international political institutions believed to be behind the current turmoil. While the 2014 survey did not collect data on these factors that would allow us to test this hypothesis, the impact of work status seems to point in that direction. Future research should focus on the test of this sort of protest nostalgia that we are hypothesising.

A second avenue of research on attitudes towards the past in Portugal has to do with the relationship between the New State and the colonial empire in Africa and Asia. A few recent studies in history and anthropology have pointed out the existence of a certain nostalgia for the empire in Portuguese society, visible in discourses on national identity (Jerónimo \& Pinto 2015; Leal 2009). Added value for our understanding of the determinants of attitudes towards the past, particularly the differences between left and right, would come from collecting data on attitudes towards the colonies and decolonisation among Portuguese citizens. This would also increase our ability to compare the Portuguese case with other European democracies, particularly post-colonial countries such as France, the UK and the Netherlands.

\section{Notes}

1. Although the Portuguese empire included territories in India, the Indian annexation of Goa in December 1961 put an end to the Portuguese presence in the region in less than two days.

2. In 2009, the Flash Eurobarometer (EB) on the 2004 Enlargement asked citizens in all member states whether they thought that 'the situation which prevailed in Central and Eastern European countries before 1989 was better than today's' (Flash EB 257).

3. The question was, 'Looking back, how do you think Franco's regime will be regarded in the future: as a positive period for Spain; as a negative period for Spain; or as a period that had good things and bad things'? ('Con la perspectiva que dan los años, ?cómo cree Vd. Que pasará a la historia el régimen de Franco: como un período positivo para España, como um período negativo para España o como una etapa que tuvo cosas buenas y cosas malas?') (CIS 1995, 2000).

4. Surveys conducted during that period as well as after Pinochet's arrest included questions such as: 'In your opinion, regarding General Augusto Pinochet's regime, do you think ...' ('En su opinión, mirando el régimen del general Augusto Pinochet, piensa que ...'); 'What is your opinion about the 17 years of General Pinochet's government? Would you say they were ...?' ('Cuál es su opinión sobre los 17 años del gobierno del general Pinochet? Diría Ud que fueron ...'(Huneeus 2003).

5. The question was, 'Which government or regime was better at ruling the country?'

6. In this section, when we mention the dependent variable in this study, the expressions'attitudes towards the past', 'attitudes towards the New State' and 'attitudes towards Salazar's regime' are used interchangeably, in order to avoid repetition.

7. The average discrete changes scores are an average of the changes in the probability of holding different attitudes caused by shifting from the minimum to the maximum value of the independent variable, when all the other variables are held at their means. These scores vary between 0 (no impact at all) and 1 (full impact); thus higher values represent a stronger mean impact. 


\section{Disclosure statement}

No potential conflict of interest was reported by the authors.

\section{Notes on contributors}

José Santana-Pereira (PhD in political and social sciences, European University Institute, Florence, 2012) is a postdoctoral research fellow at Institute of Social Sciences (ICS), University of Lisbon. His research interests comprise elections, public opinion, political attitudes and behaviour, media and politics and the organisation and effects of political campaigns. His work has been published in journals such as Electoral Studies and South European Society and Politics.

Filipa Raimundo is Postdoctoral Researcher at ICS, University of Lisbon and Guest Assistant Professor at the Lisbon University Institute (ISCTE-IUL). She obtained her PhD from the EUI with a thesis on posttransitional justice in Europe. Her interests include democratisation, transitional justice, authoritarian legacies, and quality of democracy. Her work has been published in Democratization as well as by Palgrave Macmillan and Columbia University Press.

António Costa Pinto is a research professor at the ICS, University of Lisbon. His research interests include authoritarianism, political elites, democratisation and the comparative study of political change in Southern Europe. He is the co-editor of Dealing with the legacy of authoritarianism: the 'politics of the past' in Southern European democracies (2013) (with Leonardo Morlino).

\section{References}

Aguilar Fernández, P. (2008) 'Transitional or post-transitional justice? Recent developments in the Spanish case', South European Society \& Politics, vol. 13, no. 4, pp. 417-433.

Aguilar Fernández, P. (2009) 'Whatever happened to Francoist socialisation? Spaniards' values and patterns of cultural consumption in the post-dictatorial period', Democratization, vol. 16, no. 3 , pp. 455-484.

Bacalhau, M. \& Bruneau, T. (1978) Evolução das Atitudes, Opiniões e Comportamentos Políticos dos Portugueses, Quatro anos Depois do 25 de Abril, Norma (policopied), Lisboa.

Barnes, S. (1972) 'The legacy of fascism: Generational differences in Italian political attitudes and behaviors', Comparative Political Studies, vol. 5, no. 1, pp. 41-57.

Bruneau, T. \& Bacalhau, M. (1984) Evolução das Atitudes e Comportamentos Políticos dos Portugueses, Dez Anos Depois do 25 de Abril, Norma (policopied), Lisboa.

Chu, Y., Diamond, L., Nathan, A. \& Shin, D.C. (eds) (2008). How East Asians View Democracy, Columbia University Press, New York, NY.

CIS - Centro de Investigaciónes Sociológicas. (1995) 'Barómetro Diciembre 1995, Estudio N. 2201', available online at: http://www.cis.es/cis/opencm/ES/1_encuestas/estudios/ver.jsp?estudio=1191

CIS-Centro de Investigaciónes Sociológicas. (2000)'25 Años Después - Barómetro Diciembre 2000, Estudio N 2401', available online at: http://www.cis.es/cis/opencms/-Archivos/Marginales/2400_2419/2401/ Es2401mar.pdf

Ekman, J. \& Linde, J. (2005) 'Communist nostalgia and the consolidation of democracy in Central and Eastern Europe', Communist Studies and Transition Politics, vol. 21, no. 3, pp. 354-374.

Freire, A., Lobo, M.C., Magalhães, P. \& Espírito-Santo, A. (2005) Comportamentos e Atitudes Políticas, 1973-2002, ICS, Lisboa.

Gherghina, S. \& Klymenko, L. (2012) 'Why look back? Citizens' attitudes toward the Communist regime in Belarus, Russia, and Ukraine', Problems of Post-Communism, vol. 59, no. 1, pp. 55-65.

Gunther, R., Montero, J.R. \& Botella, J. (2004) Democracy in Modern Spain, Yale University Press, New Haven, CT.

Huneeus, C. (2003) Chile un país dividido. La actualidad del pasado, Catalonia, Santiago.

Krosnick, J.A. \& Alwin, D.A. (1989) 'Aging and susceptibility to attitude change', Journal of Personality and Social Psychology, vol. 57, no. 3, pp. 416-425. 
Kurczewski, J. (1994) ‘Poland's seven middle classes', Social Research, vol. 61, no. 2, pp. 395-422.

Jerónimo, M. \& Pinto, A.C. (eds) (2015) The Ends of European Colonial Empires. Cases and Comparisons, Palgrave Macmillan, New Hampshire.

Leal, J. (2009) 'The hidden empire: Peasants, nation building and the Empire in Portuguese anthropology', in Recasting Culture and Space in Iberian Context, eds S.R. Roseman \& S.S. Parkhurst, State University of New York Press, New York, NY, pp. 35-53.

Mattes, R. (2012) 'The "Born Frees": The prospects for generational change in post-apartheid South Africa', Australian Journal of Political Science, vol. 47, no. 1, pp. 133-153.

Montero, J.R. \& Torcal, M. (1990) 'La política cultural de los españoles: pautas de continuidad y cambio', Sistema, no. 99, 39-74.

Morlino, L. \& Mattei, F. (1998) 'Old and new authoritarianism in Southern Europe', in Modern Europe After Fas, ed U. Larsen, New York, NY: Columbia University Press, pp. 1752-1774.

Pietsch, J., Miller, M. \& Karp, J. (2015) ‘Public support for democracy in transitional regimes', Journal of Elections, Public Opinion and Parties, vol. 25, no. 1, pp. 1-9.

Pinto, A.C. (2011) 'Twentieth century Portugal: An introduction', in Contemporary Portugal: Politics, Society and Culture, 2nd ed, ed A.C. Pinto, SSM/Columbia University Press, New York, NY, pp. 1-54.

Pinto, A.C. \& Raimundo, F. (2014) 'From ruptured transition to politics of silence: the case of Portugal', in Transitional Justice and Memory in Europe (1945-2013), ed N. Wouters, Intersentia, Cambridge, pp. 173-185.

Pop-Eleches, G. \& Tucker, J.A. (2014) 'Communist socialisation and post-communist economic and political attitudes', Electoral Studies, vol. 33, pp. 77-89.

Raimundo, F. (2012) 'Post-Transitional Justice? Spain, Poland, and Portugal Compared', PhD Dissertation, European University Institute, Florence.

Raimundo, F. (2015) 'Strategic silence as a third way. Political parties and transitional justice', Democratization, vol. 6, no. 22, pp. 1054-1073.

Sani, G., Santamaría, J., et al. (1985) A Cultura Política do Sul da Europa: Estudo sobre Quatro Nações, Dataset.

Stevens, D., Bishin, B. \& Barr, R. (2006) 'Authoritarian attitudes, democracy, and policy preferences among Latin American elites', American Journal of Political Science, vol. 50, no. 3, pp. 606-620. 